\title{
M1 Acetylcholine Receptor-Mediated Phosphatidylinositol Turnover in Adult and Senescent Rat Brain Slices
}

\author{
Toshio Ohnuki and Yasuyuki Nomura* \\ Department of Pharmacology, Faculty of Pharmaceutical Sciences, Hokkaido University, Sapporo O6o, Japan
}

Received May 13, $1991 \quad$ Accepted September 2, 1991

\begin{abstract}
Phosphatidylinositol (PI) turnover via muscarinic acetylcholine (mACh) receptor was investigated using the cerebral cortex from adult rats. Activities in the cerebral cortex, hippocampus and striatum from senescent rats were compared with those from adult rat. Carbachol $(1 \mathrm{mM})$-stimulated $\left[{ }^{3} \mathrm{H}\right] \mathrm{IP}$ accumulation in the presence of $10 \mathrm{mM} \mathrm{LiCl}$ was inhibited by pirenzepine more potently than by AF-DX 116 . Although the displacing activity of carbachol for $\left[{ }^{3} \mathrm{H}\right]$ pirenzepine binding was decreased by $50 \mu \mathrm{M}$ GTP $\gamma \mathrm{S}$, pretreatment of slices with pertussis toxin (PTX, 0.01-1.0 $\mu \mathrm{g} / \mathrm{ml})$ did not affect the carbachol-induced $\left[{ }^{3} \mathrm{H}\right] \mathrm{IP}$ accumulation. In the slices from all 3 tissues, cerebral cortex, hippocampus and striatum, both incorporation of $\left[{ }^{3} \mathrm{H}\right]$ inositol and carbachol-stimulated $\left[{ }^{3} \mathrm{H}\right] \mathrm{IP}$ accumulation were reduced at 28 months compared to those at 2 months. Furthermore, the $B_{\max }$ values of $\left[{ }^{3} \mathrm{H}\right]$ pirenzepine binding in membranes from these three regions were diminished at the senescent stage. Taken together, the results suggest that an $\mathbf{M}_{1}$-subtype of muscarinic acetylcholine receptor could be involved in PI turnover via GTP-binding proteins insensitive to PTX. Age-related changes in $\mathrm{M}_{1}$-receptor mediated PI turnover seem to be in part due to the decreased number of $\mathbf{M}_{\mathbf{1}}$-receptors with increasing age in the cerebral cortex, hippocampus and striatum; and some qualitative changes also seem to have occurred in the hippocampus of senescent rats in the $\mathrm{MACh}$ receptor-PI turnover system.
\end{abstract}

An initial observation by Macht (1) that centrally acting muscarinic acetylcholine $(\mathrm{mACh})$ receptor antagonists, such as scopolamine and atropine, impaired learning has stimulated subsequent studies on the role of central acetylcholine (ACh) neurons in learning $(2-5)$. The receptor heterogeneity concept regarding $\mathrm{mACh}$ receptors has been proposed and supported by experimental results using ligand binding $(6-9)$. Recently, five distinct cDNAs of $\mathrm{mACh}$ receptors were identified by

*To whom correspondence should be addressed. cloning $(10-14)$. mACh antagonists may exert their effects through these distinct receptor populations which may couple to different signalling mechanisms (15): 1) inhibition of adenylate cyclase, 2) activation of guanylate cyclase and 3) activation of phospholipase $C$. However, little has been clarified regarding the roles of $\mathrm{mACh}$ receptor subtypes and the involvement of GTP-binding proteins (G proteins) in phospholipase $\mathrm{C}$ activation in the brain. The present study was designed to clarify which $\mathrm{mACh}$ receptor subtype couples with phosphatidylinositol (PI) turnover and 
whether $G$ proteins mediate the signalling pathway in the cerebral cortex, hippocampus and striatum of rats. In addition, we investigated age-related changes in $\mathrm{mACh}$ receptormediated PI turnover.

\section{MATERIALS AND METHODS}

\section{Animals}

Wistar rats of both sexes were purchased from Nippon Rat, Ltd. Rats aged 2-3 months and 28-30months were used as adult and senescent animals, respectively. The animals were housed two-three to a cage under a constant light-dark cycle (light on between 7:30 and 19:30) at $22 \pm 2{ }^{\circ} \mathrm{C}$. Food and water were available ad lib.

Preparation of brain slices and treatment with pertussis toxin

Measurement of PI turnover activity using rat brain slices was essentially carried out as previously described (16-18). Adult or senescent rats were decapitated and the brains were rapidly removed. The brains were dissected into the cerebral cortex, hippocampus and striatum. Each section was chopped by a feather knife and pressed through a nylon mesh $(300 \times 300 \mu \mathrm{m})$. These chopped slices were incubated at $37^{\circ} \mathrm{C}$ for $30-45 \mathrm{~min}$ with gentle shaking in $20-30 \mathrm{ml}$ of Krebs-Ringer bicarbonate buffer ( $\mathrm{pH} 7.4$ ) having the following composition: $123 \mathrm{mM} \mathrm{NaCl}, 5.0 \mathrm{mM} \mathrm{KCl}$, $1.4 \mathrm{mM} \quad \mathrm{KH}_{2} \mathrm{PO}_{4}, \quad 0.8 \mathrm{mM} \quad \mathrm{CaCl}_{2}, \quad 1.3 \mathrm{mM}$ $\mathrm{MgSO}_{4}, 26 \mathrm{mM} \mathrm{NaHCO}$, and $10 \mathrm{mM}$ glucose. This solution was bubbled with $\mathrm{O}_{2} / \mathrm{CO}_{2}$ gas $(95 / 5, \mathrm{v} / \mathrm{v})$ before use and during incubation with tissues. Treatment with pertussis toxin (PTX) was carried out for $2 \mathrm{hr}$ at $37^{\circ} \mathrm{C}$.

\section{Assay of phosphatidylinositol turnover}

After preincubation, tissue slices $(20-30 \mu \mathrm{l})$ were aliquoted into reaction tubes containing $250 \mu 1$ of modified Krebs-Ringer bicarbonate buffer ( $\mathrm{pH}$ 7.4). The modified buffer consisted of $10 \mathrm{mM} \mathrm{LiCl}, 2.0 \mu \mathrm{Ci}$ of $\left[{ }^{3} \mathrm{H}\right]$ inositol, 113 $\mathrm{mM} \mathrm{NaCl}$ and the same concentrations of other compounds as the normal buffer. $\mathrm{LiCl}$
$(10 \mathrm{mM})$ was added to the reaction mixture to prevent the degradation of inositol 1-phosphate (IP) $(17,19)$. The reaction mixture was incubated for $1 \mathrm{hr}$ at $37^{\circ} \mathrm{C}$ and then stimulated by adding $10 \mu \mathrm{l}$ of drug solution, followed by incubation for another $1 \mathrm{hr}$. The incubation was terminated by adding $1 \mathrm{ml}$ of ice-cold Krebs-Ringer bicarbonate solution and cooling in an ice bath. The brain slices were washed three times with $1 \mathrm{ml}$ of ice-cold bicarbonate buffer.

Phospholipids were extracted by $0.94 \mathrm{ml}$ of chloroform/methanol $(1 / 2, \mathrm{v} / \mathrm{v})$. Then $0.31 \mathrm{ml}$ of chloroform and the same volume of distilled water were added to the extract. The aqueous phase separated was then applied to a column containing $0.6 \mathrm{ml}$ of AG 1-X8 (100-200 mesh, formate form; Bio-Rad) and $\left[{ }^{3} \mathrm{H}\right]$ inositol compounds were separated by the following solutions $(6 \mathrm{ml})$ : 1) $5 \mathrm{mM}$ myo-inositol (to elute the free inositol fraction), 2) $5 \mathrm{mM} \mathrm{Na} \mathrm{B}_{4} \mathrm{O}_{7}$ and $60 \mathrm{mM} \mathrm{HCOOH}$ (to elute the glycerophosphoryl-inositol fraction) and 3) $0.2 \mathrm{M}$ $\mathrm{HCOONH}_{4}$ and $0.1 \mathrm{M} \mathrm{HCOOH}$ (to elute the inositol 1-phosphate (IP) fraction). IP fractions were collected in scintillation vials containing $10 \mathrm{ml}$ of scintillation cocktail (Beckmann Ready Gel). The radioactivities were measured by a scintillation spectrometer.

Assay of cyclic AMP accumulation in cerebral cortical slices

After treatment with PTX for $2 \mathrm{hr}$ as described above, the supernatant was removed, and the tissue slices $(50 \mu \mathrm{l})$ were pipetted into tubes, each containing $150 \mu \mathrm{l}$ of reaction buffer. The reaction buffer consisted of $0.5 \mathrm{mM}$ RO 20-1724, a phosphodiesterase inhibitor, and $1 \mu \mathrm{M}$ pirenzepine to suppress $\mathbf{M}_{1}$-receptor mediated cyclic AMP (cAMP) elevation (20) in the presence or absence of $1 \mu \mathrm{M}$ forskolin/ $1 \mathrm{mM}$ carbachol in Krebs-Ringer bicarbonate buffer. The reaction mixture was incubated for $15 \mathrm{~min}$ at $37^{\circ} \mathrm{C}$, and then $0.2 \mathrm{ml}$ of $0.2 \mathrm{~N}$ ice-cold $\mathrm{HCl}$ was added to stop the reaction and to elute cAMP. The mixture was boiled for $3 \mathrm{~min}$ and then centrifuged $(15,000$ $\times g$ for $5 \mathrm{~min})$. The supernatant $(100 \mu \mathrm{l})$ was 
assayed using a Yamasa cAMP assay kit, a sensitive and specific radioimmunoassay method (21).

\section{Receptor binding assay using $P^{3} H / p$ irenzepine}

Preparation of crude synaptic membranes: $\mathrm{P}_{2}$ membranes were prepared according to the method of Nomura et al. (22). Briefly, brain tissues of male rats were homogenized in 10 volumes of ice-cold $25 \mathrm{mM}$ Tris- $\mathrm{HCl}$ buffer (pH 7.4) containing $0.32 \mathrm{M}$ sucrose using a Potter glass/teflon homogenizer. The homogenates were centrifuged at $1,000 \times g$ for 10 min, and the supernatant was then centrifuged at $50,000 \times g$ for $10 \mathrm{~min}$. The pellet was resuspended in $25 \mathrm{mM}$ Tris-HCl buffer ( $\mathrm{pH} 7.4$ ) containing $100 \mathrm{mM} \mathrm{NaCl}$. This suspension was stored at $-80^{\circ} \mathrm{C}$ until assay.

Effect of GTP $\gamma S$ on carbachol binding: A $100-\mu \mathrm{g}$ portion of the cerebral cortical $\mathrm{P}_{2}$ fractions $(200 \mu \mathrm{l})$ was suspended in $25 \mathrm{mM}$ Tris$\mathrm{HCl}$ buffer ( $\mathrm{pH} \mathrm{7.4)} \mathrm{containing} 100 \mathrm{mM} \mathrm{NaCl}$ and $5 \mathrm{mM} \mathrm{MgCl} 2$ and then incubated at $25^{\circ} \mathrm{C}$ for $1.5 \mathrm{hr}$ together with $\left[{ }^{3} \mathrm{H}\right]$ pirenzepine and increasing concentrations of carbachol $(1 \mu \mathrm{M}-$ $10 \mathrm{mM}$ ), in the presence or absence of $50 \mu \mathrm{M}$ GTP $\gamma$ S. The non-specific binding of $\left[{ }^{3} \mathbf{H}\right]-$ pirenzepine was defined as the radioactivity bound in the pellets in the presence of $1.0 \mu \mathrm{M}$ atropine. Reactions were terminated by rapid filtration through Whatman GF/B glass filters, which were washed three times with $1.5 \mathrm{ml}$ of ice-cold reaction buffer. Radioactivities on the filters were measured as described above. Data were analyzed by a previously described two-site computer model from our laboratory (23).

$\left[^{3} H\right]$ pirenzepine binding to $P_{2}$ membranes: Crude membranes of approximately $100 \mu \mathrm{g}$ protein (cerebral cortex) or $50 \mu \mathrm{g}$ protein (hippocampus and striatum) were incubated in $25 \mathrm{mM}$ Tris- $\mathrm{HCl}$ buffer (pH 7.4) containing $100 \mathrm{mM} \mathrm{NaCl}$ (final volume of $200 \mu \mathrm{l}$ ) in the presence of $10 \mathrm{nM}\left[{ }^{3} \mathrm{H}\right]$ pirenzepine and increasing concentrations of pirenzepine $(5-500$ $\mathrm{nM})$ at $25^{\circ} \mathrm{C}$ for $1.5 \mathrm{hr}$. The bound and free ligand were separated by rapid filtration through Whatman GF/B filters. Radioactiv- ities on the filters were measured. The specific binding of pirenzepine was defined as the binding inhibited by the addition of $1 \mu \mathrm{M}$ atropine.

\section{Protein assay}

The protein concentration of each sample of brain slices and $\mathrm{P}_{2}$ membranes was determined by the method of Lowry et al. (24) with bovine serum albumin as the standard.

\section{Drugs}

Myo- $\left[2-{ }^{3} \mathrm{H}(\mathrm{N})\right]$ inositol $(12.8 \mathrm{Ci} / \mathrm{mmol})$ and $\left[\mathrm{N}\right.$-methyl- $\left.{ }^{3} \mathrm{H}\right]$ pirenzepine $\quad(82.0 \mathrm{Ci} / \mathrm{mmol})$ were obtained from New England Nuclear. Drugs and an assay kit were kindly donated to us as follows: 11-[[2-[(diethylamino)methyl]-1piperidinyl]acetyl]-5,11-dihydro-6H-pyrido[2,3b] $[1,4]$ benzodiazepine-6-one, AF-DX 116, from Dr. Thomae GmbH (Biberach, F.R.G.); PTX was from Kaken Pharmaceutical Co., Ltd. (Shiga, Japan); RO 20-1724 was from Nippon Roche Research Center (Kanagawa, Japan); and a Yamasa cAMP assay kit from Yamasa Shoyu Co. (Choshi, Japan). Other drugs were obtained as follows: carbamylcholine chloride, pirenzepine dihydrochloride and bovine serum albumin from Sigma Chemical Co., Ltd. (St. Louis, MO, U.S.A); other drugs were purchased from Wako Pure Chemical Industries, Ltd. (Tokyo, Japan).

\section{Statistical significance}

Student's $t$-test was used for the evaluation of statistical significance.

\section{RESULTS}

Effects of high potassium and physostigmine on $l^{3}$ HJinositol 1-phosphate accumulation in cerebral cortical slices

Accumulations of $\left[{ }^{3} \mathrm{H}\right]$ inositol 1-phosphate $\left(\left[{ }^{3} \mathrm{H}\right] \mathrm{IP}\right)$ formed from phosphatidylinositol labelled by $\left[{ }^{3} \mathrm{H}\right]$ inositol were measured in cerebral cortical slices in Krebs-Ringer solution containing $10 \mathrm{mM} \mathrm{LiCl}$. The addition of $50 \mathrm{mM} \mathrm{KCl}$ significantly $(\mathrm{P}<0.01)$ enhanced $\left[{ }^{3} \mathrm{H}\right] \mathrm{IP}$ accumulation compared with the accu- 
mulation in normal buffer containing $5 \mathrm{mM}$ $\mathrm{KCl}$ (Fig. 1). Atropine (10 $\mu \mathrm{M})$ significantly $(\mathrm{P}<0.01)$ lowered the accumulation enhanced by high $\mathrm{KCl}$. Although physostigmine $(10 \mu \mathrm{M})$ alone did not affect $\left[{ }^{3} \mathrm{H}\right] \mathrm{IP}$ accumulation, physostigmine enhanced the accumulation by high $\mathrm{KCl}$. This enhancement by physostigmine was diminished by the addition of $10 \mu \mathrm{M}$ atropine.
Effects of pirenzepine and AF-DX 116 on carbachol-induced ${ }^{3}$ H]inositol I-phosphate accumulation

Inhibitory effects of pirenzepine (8) and AF-DX 116 (9) on carbachol-induced $\left[{ }^{3} \mathrm{H}\right] \mathrm{IP}$ formation were examined in cerebral cortical slices. Pirenzepine $(0.1 \mathrm{mM})$ completely blocked the submaximal response induced by $1 \mathrm{mM}$ carbachol, and the $\mathrm{IC}_{50}$ value was estimated as $1.15 \mu \mathrm{M}$ (Fig. 2). AF-DX 116 also inhibited

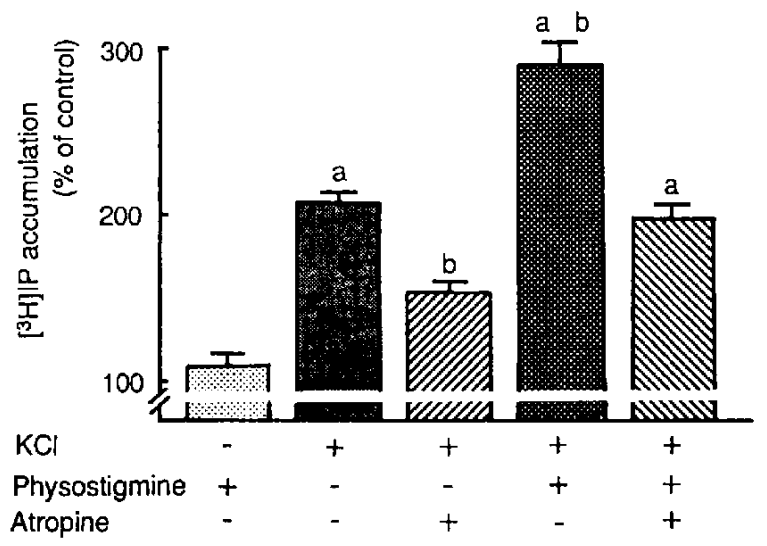

Fig. 1. The effects of physostigmine and atropine on high $\mathbf{K}^{+}$-evoked $\left[{ }^{3} \mathrm{H}\right]$ inositol 1-phosphate accumulation. After incubation with $\left[{ }^{3} \mathrm{H}\right]$ inositol, cerebral cortical slices were incubated in modified Krebs-Ringer buffer containing $50 \mathrm{mM} \mathrm{KCl}, 10 \mu \mathrm{M}$ atropine and $10 \mu \mathrm{M}$ physostigmine for $1 \mathrm{hr}$ at $37^{\circ} \mathrm{C}$. Accumulation of $\left[{ }^{3} \mathrm{H}\right] \mathrm{IP}$ is expressed as a percentage of the accumulation in slices in normal buffer. Significance: ${ }^{\mathrm{a})} \mathrm{P}<0.001$ vs. control and ${ }^{b)} \mathrm{P}<0.01$ vs. high $\mathrm{KCl}$.

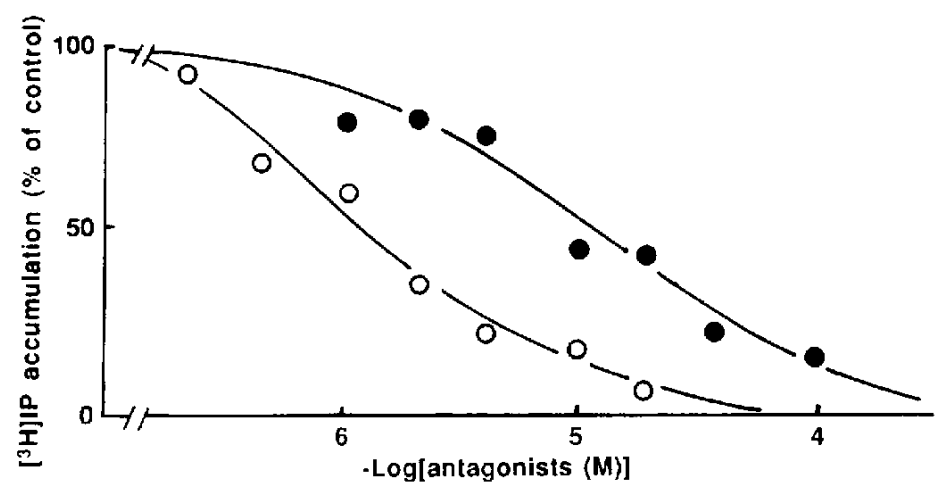

Fig. 2. Concentration-dependent inhibition by pirenzepine (O) and AF-DX $116(O)$ on $1 \mathrm{mM}$ carbacholinduced $\left[{ }^{3} \mathrm{H}\right] \mathrm{IP}$ accumulation in cerebral cortical slices. Antagonists in Krebs buffer containing $10 \mathrm{mM} \mathrm{LiCl}$ were added into the reaction mixture $5 \mathrm{~min}$ before addition of $1 \mathrm{mM}$ carbachol. 
the response with an $\mathrm{IC}_{50}$ value of $9.66 \mu \mathrm{M}$. The Hill coefficients of pirenzepine and AFDX 116 were 0.999 and 0.702 , respectively.

Inhibitory effects of carbachol on ${ }^{3} H / p i r e n-$ zepine binding in the presence or absence of GTP $\gamma S$

Using cerebral cortical membranes, the inhibitory effects of carbachol on $\left[{ }^{3} \mathrm{H}\right]$ pirenzepine binding were examined in the presence or absence of $50 \mu \mathrm{M}$ GTP $\gamma \mathrm{S}$. Total binding of $\left[{ }^{3} \mathrm{H}\right]$ pirenzepine in the presence of $\mathrm{GTP} \gamma \mathrm{S}$ was almost equal to that in the absence of GTP $\gamma$ S, but the carbachol displacement curve was shifted to the right (Fig. 3). The proportion of high affinity sites for carbachol was calculated by the two-site computer model (23) as $43.3 \%$ in the absence of GTP $\gamma \mathrm{S}$. It was decreased to $26.8 \%$ in the presence of GTP $\gamma \mathrm{S}$.

Effects of pertussis toxin on carbachol-stimulated accumulation of inositol 1-phosphate and -inhibited formation of $c A M P$

Forskolin $(1 \mu \mathrm{M})$-stimulated cAMP formation was inhibited by $62.8 \%$ by $1 \mathrm{mM}$ carbachol (Fig. 4A). The inhibitory effect was suppressed by pretreatment with PTX for $2 \mathrm{hr}$ in a concentration-dependent manner (Fig. 4A). In contrast, carbachol $(3 \mathrm{mM})$-induced accumulation of $\left[{ }^{3} \mathrm{H}\right] \mathrm{IP}$ was not significantly affected by pretreatment with PTX for $2 \mathrm{hr}$ in cerebral cortical slices. However, the accumulation was slightly enhanced by PTX (10$100 \mathrm{ng} / \mathrm{ml}$ ) in a concentration-dependent manner (Fig. 4B).

\section{Age-related changes}

Incorporation of $\left.3^{3} H\right]$ inositol into phospholipids: Incorporation of $\left[{ }^{3} \mathrm{H}\right]$ inositol into slices of cerebral cortex, hippocampus and striatum was examined in adult and senescent animals. In senescent rats, incorporation in each of the three regions was significantly decreased compared to those in adults: $8.7 \%$ (cerebral cortex), $18.1 \%$ (striatum) and $21.6 \%$ (hippocampus) (Fig. 5).

Carbachol-stimulated $P^{3}$ HJinositol I-phosphate accumulation: Concentration-response curves of carbachol-evoked $\left[{ }^{3} \mathrm{H}\right] \mathrm{IP}$ accumulation in the three brain regions of senescent rats were compared with those of adult rats. The curves obtained from the cerebral cortex and striatum data of senescent animals were

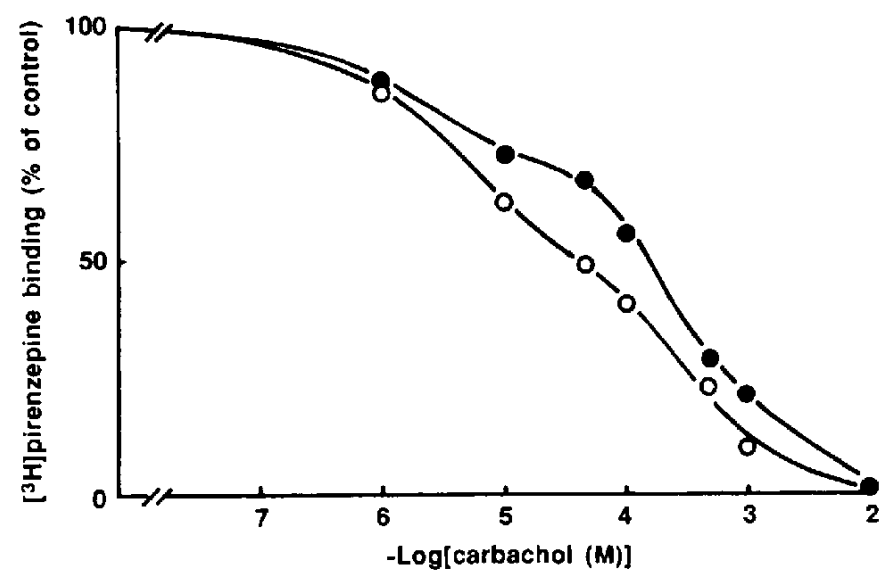

Fig. 3. The displacement of $\left[{ }^{3} \mathrm{H}\right]$ pirenzepine binding by carbachol in cortical membrane fractions in the absence $(O)$ and presence $(O)$ of $50 \mu \mathrm{M}$ GTP $\gamma$ S. Proportion of high affinity sites for carbachol changed from $43.3 \%$ (control) to $26.8 \%$ (GTP $\gamma \mathrm{S}$ ). Data were analyzed with the two-site computer model previously reported by Kitamura and Nomura (23). 

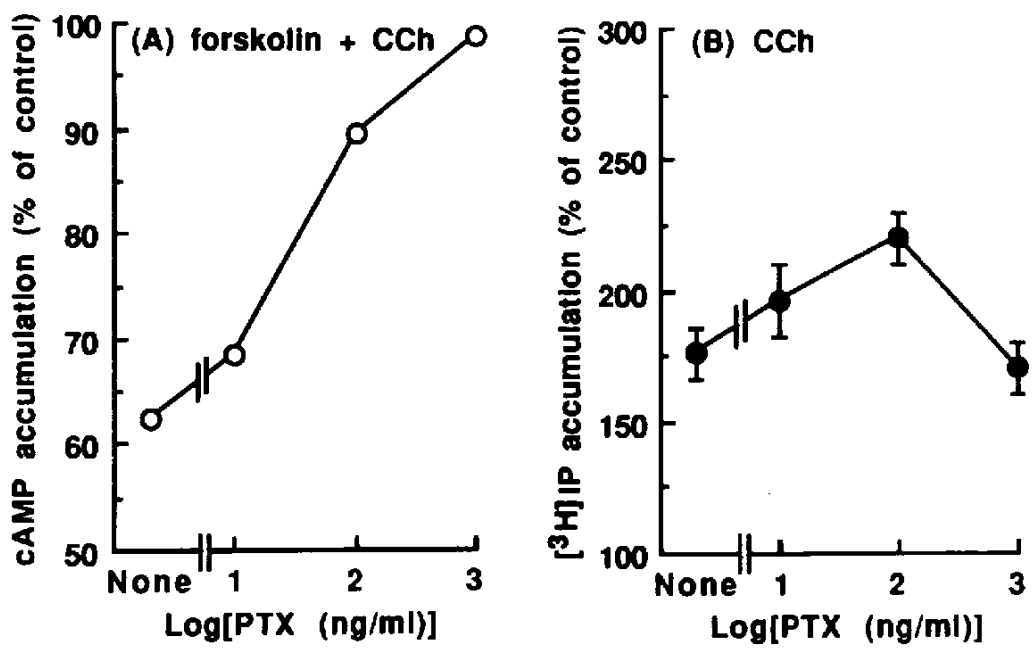

Fig. 4. Effects of pertussis toxin on $\mathrm{mACh}$ receptor-mediated changes in cAMP and $\left[{ }^{3} \mathrm{H}\right] \mathrm{IP}$ accumulation in cerebral cortical slices. PTX treatment was carried out for $2 \mathrm{hr}$ at $37^{\circ} \mathrm{C}$. A) Effects of PTX on cAMP accumulation. The ordinate shows percentage of the control cAMP level in the presence of $1 \mu \mathrm{M}$ forskolin, $1 \mathrm{mM}$ carbachol and $1 \mu \mathrm{M}$ pirenzepine without PTX treatment. Effects of PTX on cAMP level in the presence of $1 \mathrm{mM}$ carbachol, $1 \mu \mathrm{M}$ forskolin and $1 \mu \mathrm{M}$ pirenzepine were examined and plotted. B) Effects of PTX on $\left[{ }^{3} \mathrm{H}\right] \mathrm{IP}$ accumulation stimulated by $3 \mathrm{mM}$ carbachol. The ordinate shows the percentage of the control $\left[{ }^{3} \mathrm{H}\right] \mathrm{IP}$ level in the absence of carbachol

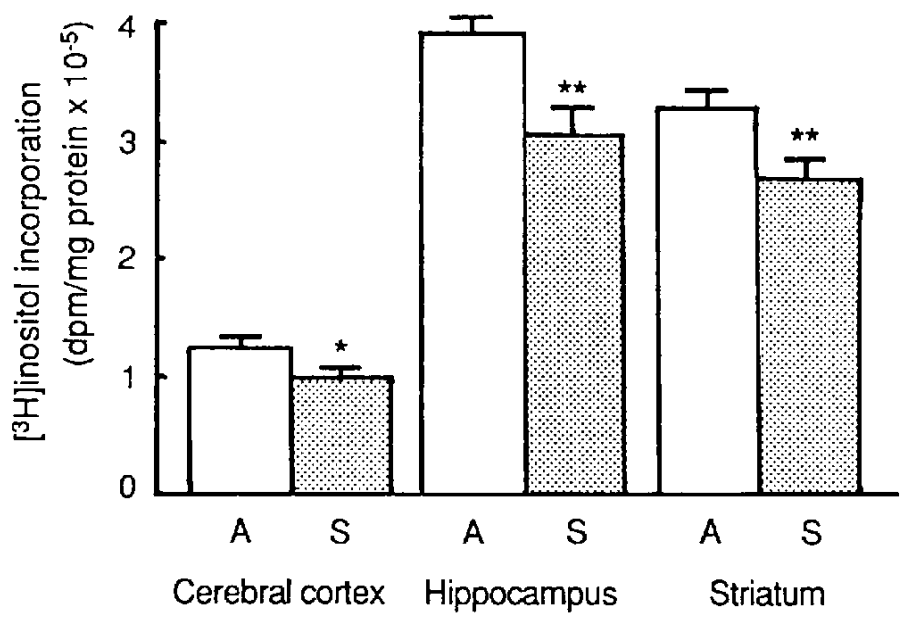

Fig. 5. Incorporation of $\left[{ }^{3} \mathrm{H}\right]$ inositol into phospholipids of tissue slices from adult and senescent rats. These data were obtained from three or five adult rats (A) and three senescent rats (S). Significance: ${ }^{\star} \mathrm{P}<0.05,{ }^{\star \star} \mathrm{P}<0.01$ vs. adult.

parallel with those obtained in adults, but were significantly shifted downward (Fig. 6, A and $\mathrm{C}$ ). In the hippocampus of senescent rats, the basal level of $\left[{ }^{3} \mathrm{H}\right] \mathrm{IP}$ formation was slightly but not significantly decreased (Fig. 6B). Carbachol-induced $\left[{ }^{3} \mathrm{H}\right] \mathrm{IP}$ accumulation was significantly $(\mathrm{P}<0.01$ or $\mathrm{P}<0.001)$ lowered in comparison to that in adults (Fig. 6B). 


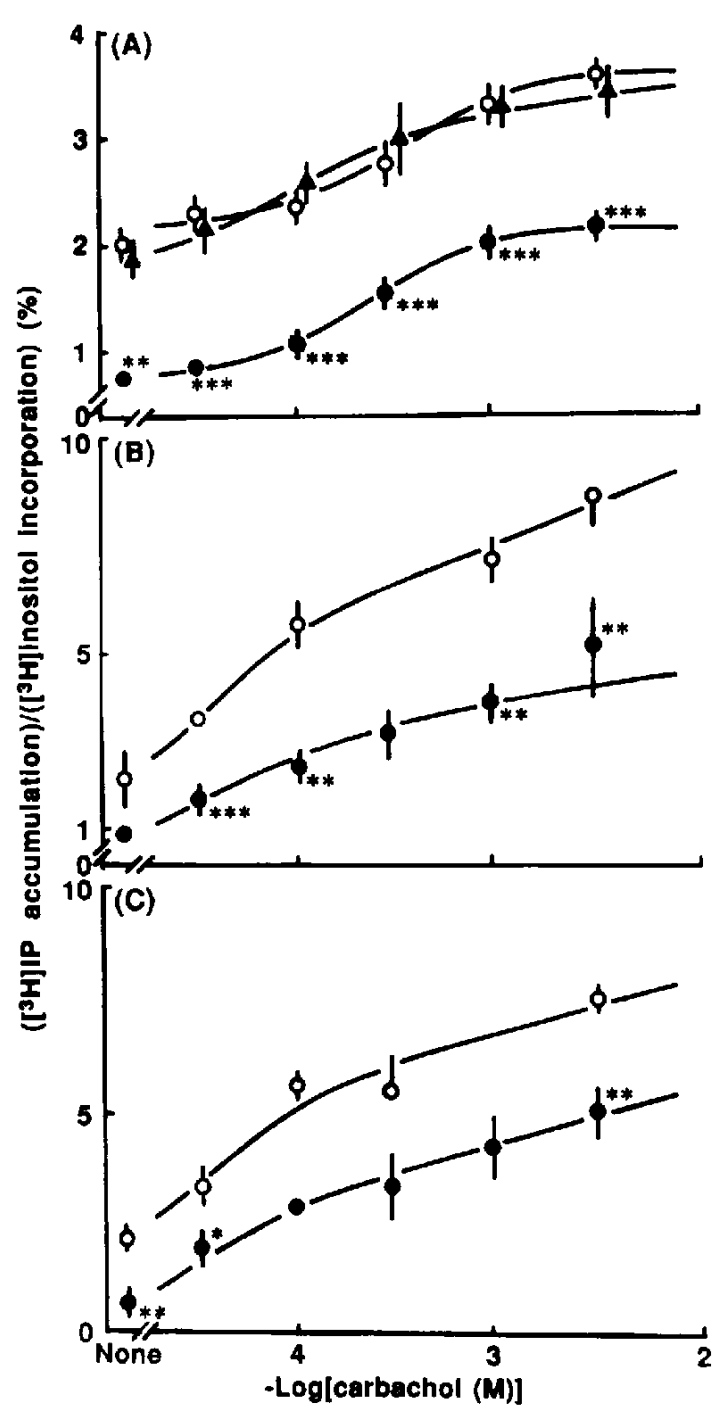

Fig. 6. Carbachol-induced $\left[{ }^{3} H\right] I P$ accumulation in cerebral cortical (A), hippocampal (B) and striatal (C) slices of adult $(O)$ and senescent rat $(O)$ and in cerebral cortical slices of 22 month-old rats $(\boldsymbol{A})$ in panel A. These data were obtained from 3-5 adult and 3 senescent rats. Data are shown as a percentage calculated as follows: $\left./\left({ }^{3} \mathbf{H}\right] \mathrm{IP}\right) /\left(\right.$ incorporation of $\left[{ }^{3} \mathbf{H}\right]$ inositol) $\} \times 100$. Significance: ${ }^{*} \mathrm{P}<0.05,{ }^{* *} \mathrm{P}<0.01$ and ${ }^{* * *} \mathrm{P}<0.001$ vs. adult.

We estimated the activity of PI turnover in cortical slices obtained from 22 month-old rats, but no significant difference was found between young rats and ones of this age (Fig.
6A).

$\Gamma^{3}$ HJpirenzepine binding to crude membranes: To elucidate age-related changes in ligand affinity and the number of binding sites of $\mathrm{M}_{1}$-receptors, Scatchard analysis of $\left[{ }^{3} \mathrm{H}\right]$ pirenzepine binding was carried out using crude synaptic membranes. The $K_{d}$ was not different between adult and senescent rats in each region. However, the $B_{\max }$ values at the senescent stage were decreased in all regions compared to adults: $35.5 \%$ in the cerebral cortex, $34.9 \%$ in the striatum and $45.5 \%$ in the hippocampus (Table 1).

\section{DISCUSSION}

The results presented here show that high concentrations of $\mathrm{KCl}$ lead to $\left[{ }^{3} \mathrm{H}\right] \mathrm{IP}$ accumulation in cerebral cortical slices. This enhancement was lowered by atropine and further increased by physostigmine, suggesting that endogenous $\mathrm{ACh}$ released by depolarizing stimulation increases $\left[{ }^{3} \mathrm{H}\right] \mathrm{IP}$ accumulation. Since atropine did not completely inhibit the accumulation enhanced by high $\mathrm{KCl}$, it is possible that other neurotransmitters may also be liberated, resulting in enhanced $\left[{ }^{3} \mathrm{H}\right] \mathrm{IP}$ accumulation. Under this experimental condition, $\mathrm{Ca}^{2+}$ may be elevated via two mechanisms as follows: 1) entry of $\mathrm{Ca}^{2+}$ through voltage-dependent $\mathrm{Ca}$ channels activated by high $\mathrm{K}^{+}$-induced depolarization and 2) intracellular mobilization of $\mathrm{Ca}^{2+}$ by inositol 1,4,5-trisphosphate $\left(\mathrm{IP}_{3}\right)$ formed by receptor stimulation. It is reported that here are several isomers of phospholipase C (PLC) and some types of PLC involved in hydrolysis of PI into IP in the presence of high concentration of $\mathrm{Ca}^{2+}(25-28)$. Intracellular $\mathrm{Ca}^{2+}$ increased by high $\mathrm{K}^{+}$may also enhance $\left[{ }^{3} \mathrm{H}\right] \mathrm{IP}$ accumulation. In the present data, atropine could not inhibit $\left[{ }^{3} \mathrm{H}\right] \mathrm{IP}$ accumulation by high $\mathrm{K}^{+}$, suggesting that other neurotransmitters and increased intracellular $\mathrm{Ca}^{2+}$ also stimulate PI turnover. However, ACh-evoked $\left[{ }^{3} \mathrm{H}\right] \mathrm{IP}$ accumulation is perhaps dominant in neurotransmitter receptor-mediated $\left[{ }^{3} \mathbf{H}\right] \mathbf{I P}$ accumulation in the cerebral cortex, since atropine markedly 
Table 1. The $K_{d}$ and $B_{\max }$ values of $\left[{ }^{3} \mathrm{H}\right]$ pirenzepine binding to brain membranes in adult and senescent rats

\begin{tabular}{lccccc}
\hline \multirow{2}{*}{ Region } & \multicolumn{2}{c}{ Adult } & & \multicolumn{2}{c}{ Senescent } \\
\cline { 2 - 3 } \cline { 5 - 6 } & $\begin{array}{c}\mathbf{K}_{\mathbf{d}} \\
(\mathbf{n M})\end{array}$ & $\begin{array}{c}\mathrm{B}_{\max } \\
(\mathrm{pmol} / \mathrm{mg} \text { protein) }\end{array}$ & $\begin{array}{c}\mathbf{K}_{\mathbf{d}} \\
(\mathrm{nM})\end{array}$ & $\begin{array}{c}\mathbf{B}_{\max } \\
(\mathrm{pmol} / \mathrm{mg} \text { protein })\end{array}$ \\
\hline Cerebral cortex & 26.0 & 1.55 & 21.1 & $1.00^{*}$ \\
Hippocampus & 38.3 & 2.42 & & 30.3 & $1.32^{*}$ \\
Striatum & 40.6 & 2.61 & & 46.4 & $1.70^{*}$ \\
\hline
\end{tabular}

$\left[{ }^{3} \mathrm{H}\right]$ pirenzepine binding to $\mathrm{P}_{2}$ membrane fractions that were obtained from five adult and three senescent rats. The mean values of $K_{d}$ and $\mathbf{B}_{\max }$ are from at least three experiments. Standard errors of each value are less than $10 \%$. Significance: ${ }^{*} \mathrm{P}<0.05$ vs. adult.

inhibited $\left[{ }^{3} \mathrm{H}\right] \mathrm{IP}$ accumulation by high $\mathrm{K}^{+}$.

Identification of five distinct cDNAs of $\mathrm{mACh}$ receptors and the expression of cloned mACh receptors have been reported $(10-14$, 29 -31). The $\mathrm{mACh}$ receptor has been pharmacologicaly classified into three subclasses, $M_{1}, M_{2}$, and $M_{3}$, according to the affinity for pirenzepine and AF-DX 116. Since the Hill coefficient of pirenzepine was unity, it is possible that pirenzepine-sensitive receptors couple to PI turnover. In contrast, the Hill coefficient of AF-DX 116 was less than unity, suggesting that 1) AF-DX 116-sensitive receptors are coupled to PI turnover with negative cooperativity, or 2) that at least two different types of receptors which have close affinities for pirenzepine and different affinities for AF-DX 116 are linked to PI turnover.

Purified $\mathrm{mACh}$ receptors have been shown to couple with $G_{i} / G_{o}$ (32). Among $G$ proteins capable of coupling receptors to PLC, which are termed $G_{p}(33)$, some are PTX-sensitive $(34-36)$ and others are insensitive $(37-39)$. GTP $\gamma \mathrm{S}$-induced reduction in carbachol affinity for $\left[{ }^{3} \mathrm{H}\right]$ pirenzepine binding suggests that $\mathrm{M}_{1}$ receptors interact with $G$ proteins. Although carbachol-stimulated PI turnover was not significantly affected by PTX treatment, PTX slightly enhanced the reactivity to carbachol. In contrast, the inhibitory effect of carbachol on forskolin-induced cAMP accumulation was suppressed by PTX, suggesting that PTX caused ADP-ribosylation of $\mathrm{G}_{\mathrm{i}} / \mathrm{G}_{\mathrm{o}}$ under the present conditions. Ashkenazi et al. $(20,40)$ proposed that specific regulation of PLC activity may be achieved by selective coupling of different receptors by multiple $G_{p}$, which activate PLC to different levels. The PTX-insensitive $G_{p}$ are substantially greater activators of PLC than PTX-sensitive $G_{p}$. The $\mathrm{m} 1$ and $\mathrm{m} 3$ receptors appear to couple to PTX-insensitive $\mathrm{G}_{\mathrm{p}}$ dominantly; on the other hand, the $\mathrm{m} 2$ and $\mathrm{m} 4$ receptors appear to couple to the PTX-sensitive $G_{p}$ and $G_{i} / G_{0}$. If the sensitivity to PTX of PTX-sensitive $G_{p}$ is lower than that of $G_{i} / G_{o}, G_{i} / G_{0}$ are preferentially ADPribosylated compared to $G_{p}$. Uncoupling of $\mathrm{G}_{\mathrm{i}} / \mathrm{G}_{\mathrm{o}}$ with $\mathrm{m} 2$ and $\mathrm{m} 4$ receptors by ADPribosylation may facilitate the signalling pathway from the receptors to PLC via $G_{p}$. This facilitation results in slight enhancement of the reactivity to carbachol.

Two different pathways of uptake, diffusion and active transport of inositol, have been reported (41-43). Decrease in the fluidity of lipid bilayer membranes and surplus formation of phospholipid peroxides as a product of reactions of radicals (44) may disturb the inositol uptake pathway at the senescent stage.

The concentration-response curves of carbachol-induced $\left[{ }^{3} \mathrm{H}\right] \mathrm{IP}$ accumulation in senescent cerebral cortical and striatal slices were shifted downward but paralleled adult curves. Such findings suggest that these age-related 
changes are quantitative and can be explained in part by a decrease in $\mathrm{M}_{1}$-receptors and/or neuronal population in the regions. In contrast, both basal activity and reactivity of IP accumulation to carbachol-stimulation declined in the hippocampus. The changes in PI response to $\mathrm{M}_{1}$-receptor stimulation in the hippocampus could be due to: 1) a decrease in the $\mathrm{M}_{1}$-receptor population, 2) a decrease in fluidity of plasma membranes (44) followed by a decline of coupling between receptors, G proteins and PLC, and 3) structural changes in $G$ proteins and/or PLC.

Reduction of $\left[{ }^{3} \mathrm{H}\right]$ inositol incorporation into senescent slices suggests a reduction in the formation of substrates for PLCs. The decline in biosynthetic activities of phosphatidylinositol phosphates and their hydrolysis and decrease in the number of $\mathbf{M}_{1}$-receptors might occur in the nervous system of rats during aging.

\section{Acknowledgment}

This work was supported in part by a Grant-in-Aid from the Akiyama Foundation, Japan.

\section{REFERENCES}

1 Macht, D.I.: A pharmacological analysis of the cerebral effects of atropine, homatropine, scopolamine and related drugs. J. Pharmacol. Exp. Ther. 22, 35-48 (1924)

2 Bartus, R.T., Dean, R.L., III, Beer, B. and Lippa, A.S.: The cholinergic hypothesis of geriatric memory dysfunction. Science 217, 408-417 (1982)

3 Hepler, D.J., Olton, D.S., Wenk, G.L. and Coyle, J.T.: Lesions in nucleus basalis magnocellularis and medial septal area of rats produce qualitatively similar memory impairment. J. Neurosci. 5, 866-873 (1985)

4 Knowlton, B., Wenk, G., Olton, D. and Coyle, J.: Basal forebrain lesions produce a dissociation of trial-dependent and trial-independent memory performance. Brain Res. 345, 315-321 (1985)

5 Whishaw, I.Q., O'Connor, W.T. and Dunnett, S.B.: Disruption of central cholinergic system in the rat by basal forebrain lesions and atropine: Effects on feeding, sensorimotor behavior, locomotor activity and spatial navigation. Behav. Brain Res. 17, 103 - 115 (1985)

6 Birdsall, N.J.M. and Hulme, E.C.: Biochemical studies on muscarinic acetylcholine receptors. J. Neurochem. 27, 7-16 (1976)

7 Giachetti, A., Micheletti, R. and Montagna, E.: Cardioselective profile of AF-DX 116, a muscarine $\mathrm{M}_{2}$ receptor antagonist. Life Sci. 38, 1663-1672 (1986)

8 Hammer, R., Berrie, C.P., Birdsall, N.J.M., Burgen, A.S.V. and Hulme, E.C.: Pirenzepine distinguishes between different subclasses of muscarinic receptors. Nature $\mathbf{2 8 3}, 90-92$ (1980)

9 Hammer, R., Giraldo, E., Schiavi, G.B., Monferini, E. and Ladinsky, $\mathbf{H}$.: Binding profile of a novel cardioselective muscarine receptor antagonist, AF-DX 116, to membranes of peripheral tissues and brain in the rat. Life Sci. 38, 16531662 (1986)

10 Bonner, T.I., Buckley, N.J., Young, A.C. and Brann, M.R.: Identification of a family of muscarinic acetylcholine receptor genes. Science 237, $527-532$ (1987)

11 Kubo, T., Fukuda, K., Mikami, A., Maeda, A., Takahashi, H., Mishina, M. et al.: Cloning, sequencing and expression of complementary DNA encoding the muscarinic acetylcholine receptor. Nature 323, 411-416 (1986)

12 Kubo, T., Maeda, A., Sugimoto, K., Akiba, I., Mikami, A., Takahashi, H. et al.: Primary structure of porcine cardiac muscarinic acetylcholine receptor deduced from the cDNA sequence. FEBS Lett. 209, 367-372 (1986)

13 Liao, C.F., Themmen, A.P.N., Joho, R., Barberis, C., Bimbaumer, M. and Birnbaumer, L.: Molecular cloning and expression of a fifth muscarinic acetylcholine receptor. J. Biol. Chem. 264, $7328-7337$ (1989)

14 Peralta, E.G., Winslow, J.W., Ashkenazi, A., Smith, D.H., Ramachandran, J. and Capon, D.J.: Structural basis of muscarinic acetylcholine receptor subtype diversity. Trends Pharm. Sci. Supp. 6- 11 (1988)

15 Brown, J.H. and Brown, S.L.: Agonists differentiate muscarinic receptors that inhibit cyclic AMP formation from those that stimulate phosphoinositide metabolism. J. Biol. Chem. 259, 3777-3781 (1984)

16 Berridge, M.J., Dawson, R.M.C., Downes, C.P., Heslop, J.P. and Irvine, R.F.: Changes in the levels of inositol phosphates after agonist-dependent hydrolysis of membrane phosphoinositides. Biochem. J. 212, 473-482 (1983)

17 Berridge, M.J., Downes, C.P. and Hanley, M.R.: Lithium amplifies agonist-dependent phosphatidylinositol responses in brain and salivary glands. Biochem. J. 206, 587-595 (1982) 
18 Jacobson, M.D., Wusteman, M. and Downes, C.P.: Muscarinic receptors and hydrolysis of inositol phospholipids in rat cerebral cortex and parotid gland. J. Neurochem. 44, 465-472 (1985)

19 Batty, I. and Nahorski, S.R.: Differential effects of lithium on muscarinic receptor stimulation of inositol phosphates in rat cerebral cortex slices. $\mathbf{J}$. Neurochem. 45, 1514-1521 (1985)

20 Ashkenazi, A., Peralta, E.G., Winslow, J.W., Ramachandran, J. and Capon, D.J.: Functional diversity of muscarinic receptor subtypes in cellular transduction and growth. Trends Pharmacol. Sci. Supp. 16-22 (1989)

21 Honma, M., Sato, T., Takezawa, J. and Ui, M.: An ultrasensitive method for the simultaneous determination of cyclic AMP and cyclic GMP in small-volume samples from blood and tissue. Biochem. Med. 18, 257-273 (1977)

22 Nomura, Y., Yotsumoto, I., Motomori-Suzaki, E., Kawai, M. and Segawa, T.: Influence of isoproterenol pretreatment on cerebral cortical bindings of $\left[{ }^{3} \mathrm{H}\right]$ clonidine and $\left[{ }^{3} \mathrm{H}\right]$ dihydroalprenolol in infant and adult rats. Dev. Brain Res. 9, 381 - 384 (1983)

23 Kitamura, Y. and Nomura, Y.: Enhancement of $\left[{ }^{3} \mathrm{H}\right]$ clonidine binding to rat cerebral synaptic membranes by treatment with arachidonic acid, prostaglandin (PG) $\mathrm{D}_{2}, \mathrm{PGE}_{2}$ and $\mathrm{PGF}_{2 \pi}$. Japan. J. Pharmacol. 42, 321-324 (1986)

24 Lowry, O.H., Rosebrough, N.J., Farr, A.L. and Randall, R.J.: Protein measurements with the Folin phenol reagent. J. Biol. Chem. 193, 265275 (1951)

25 Homma, Y., Imaki, J., Nakanishi, $O$. and Takenawa, T.: Isolation and characterization of two different forms of inositol phospholipidspecific phospholipase $\mathrm{C}$ from rat brain. J. Biol. Chem. 263, 6592-6598 (1988)

26 Katan, M. and Parker, P.J.: Purification of phosphoinositide-specific phospholipase $\mathrm{C}$ from a particulate fraction of bovine brain. Eur. J. Biochem. 168, 413-418 (1987)

27 Ryu, S.H., Cho, K.S., Lee, K.Y., Suh, P.G. and Rhee, S.G. Purification and characterization of two immunologically distinct phosphoinositidespecific phospholipase $\mathrm{C}$ from bovine brain. J. Biol. Chem. 262, $12511-12518$ (1987)

28 Ryu, S.H., Cho, K.S., Lee, K.Y., Suh, P.G. and Rhee, S.G.: Two forms of phosphatidylinositolspecific phospholipase C from bovine brain. Biochem. Biophys. Res. Commun. 141, 137-144 (1986)

29 Akiba, I., Kubo, T., Maeda, A., Bujo, H., Nakai, J., Mishina, M. et al.: Primary structure of porcine muscarinic acetylcholine receptor III and antagonist binding studies. FEBS Lett. 235, 257-261 (1988)

30 Ashkenazi, A., Winslow, J.W., Peralta, E.G., Peterson, G.L., Schimerlik, M.I., Capon, D.J. et al.: An $\mathbf{M}_{2}$ muscarinic receptor subtype coupled to both adenylyl cyclase and phosphoinositide turnover. Science 238, 672-675 (1987)

31 Fukuda, K., Kubo, T., Akiba, I., Maeda, A., Mishina, M. and Numa, S.: Molecular distinction between muscarinic acetylcholine receptor subtypes. Nature 327, 623-625 (1987)

32 Haga, K., Haga, T. and Ichiyama, A.: Reconstitution of the muscarinic acetylcholine receptor. J. Biol. Chem. 261, 10133-10140 (1986)

33 Cockcroft, S. and Gomperts, B.D.: Role of guanine nucleotide binding protein in the activation of polyphosphoinositide phosphodiesterase. Nature 314, 534 - 536 (1985)

34 Brass, L.F., Laposta, M., Banga, H.S. and Rittenhouse, S.E.: Regulation of the phosphoinositide hydrolysis pathway in thrombin-stimulated platelets by a pertussis toxin-sensitive guanine nucleotide-binding protein. J. Biol. Chem. 261, 1683816847 (1986)

35 Brass, L.F., Woolkalis, M.J. and Manning, D.R.: Interactions in platelets between $G$ proteins and the agonists that stimulate phospholipase $\mathrm{C}$ and inhibit adenylyl cyclase. J. Biol. Chem. 263, 53485355 (1988)

36 Paris, S. and Pouyssegur, J.: Pertussis toxin inhibits thrombin-induced activation of phosphoinositide hydrolysis and $\mathrm{Na}^{+} / \mathrm{H}^{+}$exchange in hamster fibroblasts. EMBO J. 5, 55-60 (1986)

37 Chiba, T., Raffoul, K. and Yamada, T.: Divergent stimulatory and inhibitory actions carbamoylcholine on gastric D-cells. J. Biol. Chem. 252, 84678469 (1987)

38 Dunlop, M.E. and Larkins, R.G.: Muscarinicagonist and guanine nucleotide activation of polyphosphoinositide phosphodiestrase in isolated islet-cell membranes. Biochem. J. 240, 731-737 (1986)

39 Masters, S.B., Martin, M.W., Harden, T.K. and Brown, J.H.: Pertussis toxin does not inhibit muscarinic-receptor-mediated phosphoinositide hydrolysis or calcium mobilizing action. Biochem. J. 227, $933-937$ (1985)

40 Peralta, E.G., Ashkenazi, A., Winslow, J.W. Ramachandran, J. and Capon, D.J.: Differential regulation of PI hydrolysis and adenylyl cyclase by muscarinic receptor subtypes. Nature 334, 434437 (1988)

41 Hotta, N., Kakuta, H., Fukusawa, H., Kimura, M., Koh, N., Matumae, H. et al.: Efficacy of glucose, ouabain and aldose reductase inhibitor on 2- 
$\left[{ }^{3} \mathrm{H}\right]$ myo-inositol uptake by human, rat and rabbit erythrocytes. Horm. Metab. Res. 20, 387-390 (1988)

42 Howerton, T.C. and Rutledge, C.O.: $\left[{ }^{3} \mathrm{H}\right]-m y o-$ inositol uptake in rat cortical slices: Identification of $\mathrm{Na}^{+}$-dependent and $\mathrm{Na}^{+}$-independent systems. Biochem. Pharmacol. 37, 911-915 (1988)

43 Tuersley, M.D., Best, L. and Tomlinson, S.:
Inositol uptake and metabolism in molluscan neuronal tissue. J. Neurochem. 51, 1610-1616 (1988)

44 Nagy, K., Simon, P. and Zu.-Nagy, I.: Spin label studies on synaptosomal membranes of rat brain cortex during aging. Biochem. Biophys. Res. Commun. 117, 688-694 (1983) 